\title{
The effect of herbal feed additive on the growth performance, carcass characteristics and meat quality of broiler chickens fed low-energy diets
}

\author{
Krzysztof Lipiński, Zofia Antoszkiewicz, Sylwia Kotlarczyk, Magdalena Mazur-Kuśnirek, \\ Joanna Kaliniewicz, and Zbigniew Makowski \\ Department of Animal Nutrition and Feed Science, University of Warmia and Mazury in Olsztyn, \\ 10-719 Olsztyn, Poland
}

Correspondence: Krzysztof Lipiński (krzysztof.lipinski@uwm.edu.pl)

Received: 10 September 2018 - Accepted: 18 December 2018 - Published: 22 January 2019

\begin{abstract}
The aim of this study was to determine the effect of herbal feed additive on growth performance, carcass characteristics, the chemical composition of breast muscles and selected meat quality parameters in broiler chickens. The experiment was performed on 1080 Ross 308 chickens, which were randomly divided into six groups with six replicates per group. In experimental groups, dietary energy concentration was reduced by 0.10 or $0.25 \mathrm{MJ} \mathrm{kg}^{-1}$, and the diets were or were not supplemented with the Superliv herbal formula at $500 \mathrm{~g} \mathrm{t}^{-1}$ of diet. A statistical analysis revealed that Superliv had a beneficial influence on the final body weights (BWs) of birds, average daily gain (ADG), feed conversion ratio (FCR), European Efficiency Index (EEI) and the proportion of heart relative to total carcass weight. However, meat acidity measured $15 \mathrm{~min}$ post mortem was higher in experimental groups. A decrease in dietary energy concentration contributed to a highly significant increase in the water-holding capacity (WHC) of meat and natural drip loss, an increase in $\mathrm{pH}_{15}$, an increase in color lightness, a decrease in redness, an increase in the fat content of meat, and a decrease in malondialdehyde
\end{abstract} (MDA) concentration.

\section{Introduction}

Stimulation of the immune system and antioxidant defense in poultry has been a topical issue since the introduction of the ban on the use of antibiotics as growth promoters in animal feed. There is a demand for alternative feed additives that promote the growth of animals without negative side effects such as the antibiotic resistance of pathogenic strains. The beneficial influence of probiotics, prebiotics, acidifiers, enzymes and herbs on gut microbiota in monogastric animals has been widely researched. Herbs and spices contain numerous active ingredients which can exert various effects (bactericidal, immunomodulatory and antioxidant) on animals. Thus, they can affect the health status and productivity of animals as well as the quality of animal products (Madhupriya et al., 2018). However, the intensity and direction of the effects exerted by herbal preparations are difficult to predict. They are mostly determined by the concentrations of active ingredients but may also be influenced by the presence of auxiliary substances and interactions with other active ingredients or feed components (Hashemi and Davoodi, 2011; Ogbuewu et al., 2018). Herbs and herbal extracts have been used in poultry production for years. Superliv is one of such herbal formulations. Due to the presence of multiple active ingredients, Superliv may exert multidirectional effects on animals, including the stimulation of their growth, performance and digestion. It may also act as a hepatoprotective agent that neutralizes toxins. The composition of diets supplemented with herbal extracts can be modified, e.g., by reducing their energy concentration. Stimulation of the liver's functions may affect a superior nutrient's digestibility and have a gainful effect on energy utilization. Thus, it can allow us to achieve high growth performance with lower energy concentrations in the diets.

The objective of this study was to determine the effect of the Superliv herbal formula on the growth performance, car- 
Table 1. Composition and nutritional value of diets for broiler chickens.

\begin{tabular}{|c|c|c|c|c|}
\hline Composition & $\begin{array}{r}\text { Starter I } \\
\text { days 0-10 }\end{array}$ & $\begin{array}{r}\text { Grower I } \\
\text { days } 11-21\end{array}$ & $\begin{array}{r}\text { Grower II } \\
\text { days 22-35 }\end{array}$ & $\begin{array}{r}\text { Finisher } \\
\text { days } 36-42\end{array}$ \\
\hline Soybean meal & 29.66 & 23.89 & 20.84 & 16.97 \\
\hline Wheat & 29.34 & 36.17 & 41.39 & 45.59 \\
\hline Maize & 25.00 & 20.00 & 15.00 & 10.00 \\
\hline Triticale & 5.00 & 6.00 & 8.00 & 10.00 \\
\hline Rapeseed meal & 4.00 & 6.00 & 6.00 & 8.00 \\
\hline Soybean oil & 3.10 & 4.30 & 5.30 & 6.31 \\
\hline DL methionine & 0.25 & 0.22 & 0.23 & 0.18 \\
\hline$L$ lysine & 0.24 & 0.29 & 0.32 & 0.35 \\
\hline$L$ threonine & 0.04 & 0.08 & 0.09 & 0.09 \\
\hline Limestone & 1.22 & 1.20 & 1.17 & 1.10 \\
\hline Monocalcium phosphate & 1.12 & 0.88 & 0.70 & 0.54 \\
\hline Sodium bicarbonate & 0.21 & 0.16 & 0.14 & 0.12 \\
\hline Premix & 0.50 & 0.50 & 0.50 & 0.50 \\
\hline Nutritional value metabolizable energy, $\mathrm{MJ} \mathrm{kg}^{-1}$ & 12.38 & 12.80 & 13.18 & 13.47 \\
\hline Crude protein, $\mathrm{g} \mathrm{kg}^{-1}$ & 215.0 & 200.0 & 190.0 & 180.0 \\
\hline Lysine, $\mathrm{g} \mathrm{kg}^{-1}$ & 12.80 & 12.00 & 11.50 & 11.00 \\
\hline Methionine + cystine, $\mathrm{g} \mathrm{kg}^{-1}$ & 9.50 & 9.00 & 8.70 & 8.10 \\
\hline Calcium, $\mathrm{g} \mathrm{kg}^{-1}$ & 9.50 & 9.00 & 8.50 & 8.00 \\
\hline Available phosphorus $\mathrm{g} \mathrm{kg}^{-1}$ & 4.50 & 4.00 & 3.60 & 3.30 \\
\hline Sodium, $\mathrm{g} \mathrm{kg}^{-1}$ & 1.80 & 1.60 & 1.60 & 1.60 \\
\hline
\end{tabular}

Table 2. Experimental design.

\begin{tabular}{lll}
\hline Group & & Experimental factor \\
\hline 1 & Positive control (PC) & - \\
2 & PC + herbal feed additive & + herbal feed additive $500 \mathrm{~g} \mathrm{t}^{-1}$ \\
3 & Negative control (NC) & $-0.10 \mathrm{MJ} \mathrm{kg}^{-1}$ \\
4 & NC + herbal feed additive & $-0.10 \mathrm{MJ} \mathrm{kg}^{-1}+$ herbal feed additive $500 \mathrm{~g} \mathrm{t}^{-1}$ \\
5 & Negative control (NC) & $-0.25 \mathrm{MJ} \mathrm{kg}^{-1}$ \\
6 & NC + herbal feed additive & $-0.25 \mathrm{MJ} \mathrm{kg}^{-1}+$ herbal feed additive $500 \mathrm{~g} \mathrm{t}^{-1}$ \\
\hline
\end{tabular}

cass characteristics and meat quality of broiler chickens fed low-energy diets.

\section{Materials and methods}

The experiment was approved by the Local Ethics Committee for Animal Experimentation in Olsztyn, Poland. The experiment was conducted on 1080 Ross 308 broiler chickens (male), which were randomly divided into six groups with six replicates per group and 30 birds per subgroup. Broiler chickens were raised on litter under standard housing conditions. The experiment lasted for 6 weeks. The birds were fed complete diets, and the feeding period was divided into four phases. The composition and nutritional value of diets were adjusted to meet the changing nutrient requirements of birds (Table 1). Control group birds received diets with standard energy concentration and without the herbal formula. In experimental groups, dietary energy concentration was re- duced by 0.10 or $0.25 \mathrm{MJ} \mathrm{kg}^{-1}$, and the diets were or were not supplemented with the herbal formula (Table 2). The Superliv herbal formula (Ayurvet; Delhi, India) contains the following herbs: Ichnocarpus frutescens, Terminalia chebula, Sida cordifolia, Terminalia arjuna, Phyllanthus emblica, Tephrosia purpurea, Fumaria indica, Andrographis paniculata, Azadirachta indica, Tinospora cordifolia, Achyranthes aspera, Boerhavia diffusa, Solanum nigrum, Citrullus colocynthis, Eclipta alba, Aphanamixis polystachya and Phyllanthus niruri. The growth-promoting and liver protective effects of the active ingredients contained in the above herbs have been documented. Superliv has been found to improve nutrient utilization and feed efficiency.

The measurements performed during the experiment were used to calculate the feed conversion ratio (FCR) and European Efficiency Index (EEI). After slaughter, two birds per subgroup were used to determine carcass characteristics (dressing percentage, percentage content of breast muscles, 
Table 3. Results of growth trial.

\begin{tabular}{|c|c|c|c|c|c|}
\hline Experimental factor & $\begin{array}{l}\text { Final body } \\
\text { weight, kg }\end{array}$ & $\begin{array}{l}\text { Average daily } \\
\text { gain, } g\end{array}$ & $\begin{array}{l}\text { Feed conversion } \\
\text { ratio, } \mathrm{kg} \mathrm{kg}^{-1}\end{array}$ & $\begin{array}{l}\text { Mortality } \\
\text { rate, } \%\end{array}$ & $\begin{array}{l}\text { EEI* } \\
\text { points }\end{array}$ \\
\hline$K$ & $2.81^{\mathrm{BCc}}$ & $65.9^{\mathrm{BCc}}$ & $1.62^{\mathrm{BCc}}$ & 3.33 & $398.0^{\mathrm{By}}$ \\
\hline$K+S$ & $2.85^{\mathrm{bcx}}$ & $67.1^{\mathrm{y}}$ & $1.54^{\mathrm{Aa}}$ & 0.00 & $440.5^{\mathrm{Aa}}$ \\
\hline$K-0.10 \mathrm{MJ} \mathrm{kg}^{-1}$ & $2.85^{\mathrm{bcx}}$ & $66.9^{\mathrm{bcxy}}$ & $1.62^{\mathrm{ABCby}}$ & 4.67 & $400.5^{\text {byz }}$ \\
\hline$K-0.10 \mathrm{MJ} \mathrm{kg}^{-1}+S$ & $2.93^{\mathrm{Aa}}$ & $68.8^{\mathrm{Aax}}$ & $1.57^{\mathrm{ABabx}}$ & 4.00 & $426.7^{\text {abxy }}$ \\
\hline$K-0.25 \mathrm{MJ} \mathrm{kg}^{-1}$ & $2.78^{\mathrm{Cy}}$ & $65.3^{\mathrm{Cz}}$ & $1.64^{\mathrm{C}}$ & 4.00 & $368.6^{\mathrm{Bc}}$ \\
\hline$K-0.25 \mathrm{MJ} \mathrm{kg}^{-1}+S$ & $2.90^{\mathrm{ABab}}$ & $68.1^{\mathrm{ABab}}$ & $1.57^{\mathrm{Babx}}$ & 4.29 & $423.5^{\text {bax }}$ \\
\hline \multicolumn{6}{|l|}{ Analysis of variance } \\
\hline SEM & 0.013 & 0.313 & 0.009 & 0.53 & 5.006 \\
\hline$P$ & 0.003 & 0.003 & 0.002 & 0.12 & 0.004 \\
\hline \multicolumn{6}{|l|}{ Energy } \\
\hline$K$ & $2.83^{\mathrm{x}}$ & 66.46 & 1.58 & $1.67^{\mathrm{x}}$ & 419.25 \\
\hline$K-0.10 \mathrm{MJ} \mathrm{kg}^{-1}$ & $2.88^{\mathrm{y}}$ & 67.69 & 1.6 & $4.33^{\mathrm{y}}$ & 413.62 \\
\hline$K-0.25 \mathrm{MJ} \mathrm{kg}^{-1}$ & 2.84 & 66.68 & 1.61 & $4.00^{\mathrm{y}}$ & 405 \\
\hline \multicolumn{6}{|l|}{ Superliv } \\
\hline- & $2.81^{\mathrm{A}}$ & $66.09^{\mathrm{A}}$ & $1.63^{\mathrm{A}}$ & 4.00 & $393.73^{\mathrm{A}}$ \\
\hline+ & $2.89^{\mathrm{B}}$ & $67.98^{\mathrm{B}}$ & $1.56^{\mathrm{B}}$ & 2.67 & $430.22^{\mathrm{B}}$ \\
\hline Analysis of variance & & & $P$ & & \\
\hline Energy $(E)$ & 0.099 & 0.112 & 0.427 & 0.073 & 0.347 \\
\hline Superliv $(S)$ & $<0.001$ & $<0.001$ & $<0.001$ & 0.187 & $<0.001$ \\
\hline Interaction $(E \times S)$ & 0.388 & 0.396 & 0.663 & 0.357 & 0.812 \\
\hline SEM & 0.013 & 0.313 & 0.009 & 0.53 & 0.313 \\
\hline
\end{tabular}

* European Efficiency Index. ${ }^{\text {a, }}{ }^{2} P \leq 0.05 .{ }^{A}, \mathrm{~B}, \mathrm{C} P \leq 0.01 .{ }^{\mathrm{x} / \mathrm{y} / \mathrm{z}} 0.05<P \leq 0.10$.

abdominal fat, heart and liver in total carcass weight), the proximate chemical composition of breast muscles (content of dry matter, crude ash, crude protein and crude fat) according to AOAC (2005), the physicochemical parameters of breast muscles, $\mathrm{pH}_{15}, \mathrm{pH}_{24}$, color in CIE L*a*b* $\left(\mathrm{L}^{*}-\right.$ lightness; $a^{*}$ - redness; $b^{*}$ - yellowness) (CIE, 1978) with the Hunter Lab Mini Scan XE Plus spectrophotometer, $24 \mathrm{~h}$ post mortem, water-holding capacity (WHC; by the Grau and Hamm method, 1952, modified by Pohja and Niinivaara, 1957), natural drip loss (by the method proposed by Honikel, 1998) and malondialdehyde (MDA) concentration (as described by Sorensen and Jorgensen, 1996). The results were processed by two-way analysis of variance (ANOVA) and Duncan's test. Arithmetic means $(x)$, standard error of the mean (SEM), significance level $(P \leq 0.05, P \leq 0.01)$ and statistical tendencies $x, y(P>0.05, P \leq 0.1)$ were calculated using STATISTICA 12.0 software.

\section{Results}

The Superliv herbal formula had a positive effect on nearly all performance parameters in broiler chickens. The product's beneficial influence on mortality rates was not statisti- cally significant, whereas mortality tended to increase with decreasing dietary energy concentration. Low-energy diets had no significant effect on the remaining parameters of growth performance. No interactions were found between the experimental factors (Table 3).

Superliv neither reduced dietary energy concentration nor affected carcass dressing percentage or the percentage content of breast muscles and abdominal fat in the carcass (Table 4). Highly significant differences were noted in the percentage content of heart in total carcass weight (Table 4). Heart weight increased in chickens fed diets supplemented with Superliv and tended to decrease with decreasing dietary energy concentration.

Table 5 presents the chemical composition and MDA content of breast muscles. Neither the chemical composition of breast muscles nor MDA concentration were affected by the herbal feed additive. Fat content and susceptibility to lipid peroxidation were influenced by energy concentration in the ration. Crude fat content was highly significantly and significantly higher in the breast muscles of broilers fed low-energy diets. The breast muscles of birds from groups 5 and 6 had the lowest MDA concentration and the highest fat content. 
Table 4. Carcass characteristics.

\begin{tabular}{|c|c|c|c|c|c|}
\hline \multirow[b]{2}{*}{ Specification } & \multirow[b]{2}{*}{$\begin{array}{l}\text { Dressing } \\
\text { percentage, } \%\end{array}$} & \multicolumn{4}{|c|}{ Percentage in total carcass weight, $\%$} \\
\hline & & $\begin{array}{l}\text { Breast } \\
\text { muscles }\end{array}$ & $\begin{array}{l}\text { Abdominal } \\
\text { fat }\end{array}$ & Heart & Liver \\
\hline \multicolumn{6}{|l|}{ Diet } \\
\hline$K$ & $73.11^{\mathrm{y}}$ & 30.97 & 1.03 & $0.64^{\mathrm{yz}}$ & $2.99^{\mathrm{x}}$ \\
\hline$K+S$ & 73.56 & 30.55 & 0.88 & $0.70^{\mathrm{ax}}$ & 2.70 \\
\hline$K-0.10 \mathrm{MJ} \mathrm{kg}^{-1}$ & 73.79 & 30.90 & 0.94 & $0.62^{\mathrm{bc}}$ & $3.00^{\mathrm{x}}$ \\
\hline$K-0.10 \mathrm{MJ} \mathrm{kg}^{-1}+S$ & 73.43 & 30.58 & 0.89 & $0.64^{\mathrm{y}}$ & 2.76 \\
\hline$K-0.25 \mathrm{MJ} \mathrm{kg}^{-1}$ & 73.63 & 30.42 & 1.09 & $0.58^{\mathrm{cz}}$ & 2.69 \\
\hline$K-0.25 \mathrm{MJ} \mathrm{kg}^{-1}+S$ & $74.41^{\mathrm{x}}$ & 30.48 & 0.98 & $0.66^{\mathrm{ab}}$ & $2.64^{\mathrm{y}}$ \\
\hline \multicolumn{6}{|l|}{ Analysis of variance } \\
\hline SEM & 0.178 & 0.207 & 0.040 & 0.010 & 0.054 \\
\hline$P$ & 0.428 & 0.965 & 0.652 & 0.013 & 0.206 \\
\hline \multicolumn{6}{|l|}{ Energy } \\
\hline$K$ & 73.34 & 30.76 & 0.96 & $0.67^{\mathrm{x}}$ & 2.85 \\
\hline$K-0.10 \mathrm{MJ} \mathrm{kg}^{-1}$ & 73.61 & 30.74 & 0.92 & $0.63^{\mathrm{y}}$ & 2.88 \\
\hline$K-0.25 \mathrm{MJ} \mathrm{kg}^{-1}$ & 74.02 & 30.45 & 1.03 & $0.62^{y}$ & 2.66 \\
\hline \multicolumn{6}{|l|}{ Superliv } \\
\hline- & 73.51 & 30.76 & 1.02 & $0.61^{\mathrm{A}}$ & $2.89^{\mathrm{x}}$ \\
\hline+ & 73.80 & 30.53 & 0.92 & $0.67^{\mathrm{B}}$ & $2.70^{\mathrm{y}}$ \\
\hline Analysis of variance & & & $P$ & & \\
\hline Energy $(E)$ & 0.297 & 0.807 & 0.502 & 0.076 & 0.206 \\
\hline Superliv $(S)$ & 0.416 & 0.596 & 0.198 & 0.004 & 0.074 \\
\hline Interaction $(E \times S)$ & 0.405 & 0.891 & 0.894 & 0.461 & 0.641 \\
\hline SEM & 0.178 & 0.207 & 0.040 & 0.010 & 0.054 \\
\hline
\end{tabular}

a, b $P \leq 0.05 .{ }^{A}$, B, C $P \leq 0.01 .{ }^{\mathrm{x} / \mathrm{y} / \mathrm{z}} 0.05<P \leq 0.10$

The decrease in dietary energy concentration had a significant effect on lipid peroxidation.

Superliv had no significant influence on the physicochemical properties of meat, except for $\mathrm{pH}_{15}$, which increased slightly in response to the herbal formula. Reduced energy concentration in the ration had a highly significant effect on nearly all meat quality parameters (excluding $\mathrm{pH}_{24}$ and the contribution of yellowness). A considerable decrease was noted in WHC and natural drip loss, and a minor increase was observed in $\mathrm{pH}_{15}$ and color lightness. The contribution of redness decreased in response to reduced dietary energy concentration (Table 6).

\section{Discussion}

Singh et al. (2009), who also tested Superliv in $500 \mathrm{~g} \mathrm{t}^{-1}$ of feed, noted higher final body weights and lower FCR values in broiler chickens administered the herbal liver tonic compared with the control group. Similar results were reported by Sharma et al. (2008), who investigated the efficacy of two herbal products - a liver tonic (Superliv DS, $250 \mathrm{~g} \mathrm{t}^{-1}$ ) and a growth promoter (Xlivpro) - in broiler chickens. Both products contributed to an increase in the final body weights of birds and lower feed intake per kilogram of body weight gain. In a field trial where dietary supplementation with Superliv liquid was analyzed under farm conditions, an improvement in growth performance was noted in supplemented broilers, but the increase in average daily gain (ADG) was not statistically significant in the last week of fattening (Bhattacharyya, 2013). According to the above authors, the efficacy of Superliv was higher in birds exposed to stress, pathogens and changes in energy concentration in the ration. Herbs administered to turkeys had no influence on their performance (Lipiński et al., 2011).

Previous research has not confirmed a positive effect of herbal extracts on heart weight in broiler chickens. No significant differences in heart weight were found between control and experimental groups in studies investigating mixtures of herbal plants (Al-Kassie and Witwit, 2010; Amad et al., 2011) or single herbs (Demir et al., 2008; Al-Kassie, 
Table 5. Chemical composition of breast muscles.

\begin{tabular}{|c|c|c|c|c|c|}
\hline Specification & $\begin{array}{c}\text { Dry } \\
\text { matter, \% }\end{array}$ & $\begin{array}{l}\text { Crude } \\
\text { ash, \% }\end{array}$ & $\begin{array}{c}\text { Crude } \\
\text { protein, } \%\end{array}$ & $\begin{array}{l}\text { Crude } \\
\text { fat, } \%\end{array}$ & $\begin{array}{l}\text { Malondialdehyde, } \\
\mathrm{mg} \mathrm{kg}^{-1}\end{array}$ \\
\hline \multicolumn{6}{|l|}{ Diet } \\
\hline$K$ & 26.36 & 1.15 & 23.00 & $0.91^{\mathrm{B}}$ & $0.63^{\text {abxy }}$ \\
\hline$K+S$ & 26.11 & 1.16 & 22.76 & $1.27^{\mathrm{bcyz}}$ & $0.67^{\mathrm{axy}}$ \\
\hline$K-0.10 \mathrm{MJ} \mathrm{kg}^{-1}$ & 26.58 & 1.12 & 22.46 & $1.64^{\mathrm{Axy}}$ & $0.58^{\text {abyz }}$ \\
\hline$K-0.10 \mathrm{MJ} \mathrm{kg}^{-1}+S$ & 25.97 & 1.16 & 22.51 & $1.21^{\mathrm{cz}}$ & $0.38^{\mathrm{ZV}}$ \\
\hline$K-0.25 \mathrm{MJ} \mathrm{kg}^{-1}$ & 26.22 & 1.16 & 22.57 & $1.74^{\mathrm{Aabx}}$ & $0.34^{\mathrm{bcv}}$ \\
\hline$K-0.25 \mathrm{MJ} \mathrm{kg}^{-1}+S$ & 26.58 & 1.16 & 22.76 & $1.84^{\mathrm{Aa}}$ & $0.27^{\mathrm{c}}$ \\
\hline \multicolumn{6}{|l|}{ Analysis of variance } \\
\hline SEM & 0.121 & 0.008 & 0.110 & 0.085 & 0.045 \\
\hline$P$ & 0.647 & 0.656 & 0.756 & 0.002 & 0.021 \\
\hline \multicolumn{6}{|l|}{ Energy } \\
\hline$K$ & 26.24 & 1.16 & 22.88 & $1.09^{\mathrm{Aa}}$ & $0.65^{\mathrm{Ax}}$ \\
\hline$K-0.10 \mathrm{MJ} \mathrm{kg}^{-1}$ & 26.28 & 1.14 & 22.48 & $1.43^{\mathrm{b}}$ & $0.48^{\mathrm{y}}$ \\
\hline$K-0.25 \mathrm{MJ} \mathrm{kg}^{-1}$ & 26.40 & 1.16 & 22.66 & $1.79^{\mathrm{Ba}}$ & $0.31^{\mathrm{Bx}}$ \\
\hline \multicolumn{6}{|l|}{ Superliv } \\
\hline- & 26.39 & 1.14 & 22.68 & 1.43 & 0.52 \\
\hline+ & 26.22 & 1.16 & 22.68 & 1.44 & 0.44 \\
\hline Analysis of variance & & & $P$ & & \\
\hline Energy $(E)$ & 0.861 & 0.538 & 0.378 & $<0.001$ & 0.005 \\
\hline Superliv $(S)$ & 0.506 & 0.275 & 0.998 & 0.931 & 0.317 \\
\hline Interaction $(E \times S)$ & 0.289 & 0.679 & 0.748 & 0.056 & 0.419 \\
\hline SEM & 0.121 & 0.008 & 0.110 & 0.085 & 0.045 \\
\hline
\end{tabular}

a, b, c $P \leq 0.05$. A, B, C $P \leq 0.01 .{ }^{\mathrm{x} / \mathrm{y} / \mathrm{z}} 0.05<P \leq 0.10$.

2010). The differences between the above findings and our results could be due to different dietary inclusion levels of herbs and different concentrations of active ingredients in the tested products. Inappropriate feed formulation and other nutritional mistakes may lead to morphological changes in the liver including enlargement, thus negatively affecting broiler productivity. Due to its composition, Superliv was expected to exert hepatoprotective, immunomodulatory, antioxidant and growth-promoting effects (Singh et al., 2009). In the present study, liver weight tended to decrease in response to the herbal feed additive. Our results corroborate the findings of Bhattacharyya et al. (2013), who observed enhanced activity of Superliv liquid under reduced welfare standards, in this case resulting from liver overload due to an imbalance between dietary protein and energy intake. In a study by Sharma et al. (2008), broiler chickens administered Superliv at $250 \mathrm{~g} \mathrm{t}^{-1}$ were characterized by a lower liver weight than control group birds.

Due to the high antioxidant potential of active ingredients, numerous studies have investigated the effects of herbs on the oxidative stability of lipids in poultry meat, but their re- sults are inconclusive. Some studies have revealed a decrease in MDA concentration after the application of herbal essential oils. Giannenas et al. (2005) demonstrated that the MDA content of breast muscles was significantly lower in broiler chickens fed diets supplemented with oregano oil, compared with the control group. When alpha-tocopheryl acetate was applied with oregano, MDA concentration decreased steadily. Luna et al. (2010) analyzed pure active ingredients isolated from oregano, thymol and carvacrol. Similarly to our experiment, the herbal feed additive had no significant effect on the oxidative stability of lipids in breast muscles. In the cited study, lipids extracted from thigh muscles were more susceptible to oxidation. Botsoglou et al. (2004) administered a mixture of herbal essential oils to broiler chickens with drinking water. Lipids in breast muscles were significantly less susceptible to oxidation in birds receiving oregano-derived essential oils supplemented through drinking water. Such an effect was also observed by Basmacioglu et al. (2004), who analyzed oregano and rosemary essential oils. In the current study, Superliv did not contribute to a significant decrease in MDA levels. 
Table 6. Meat quality parameters.

\begin{tabular}{|c|c|c|c|c|c|c|c|}
\hline \multirow[b]{2}{*}{ Specification } & \multirow[b]{2}{*}{$\begin{array}{l}\text { Water-holding } \\
\text { capacity, } \mathrm{cm}^{2}\end{array}$} & \multirow[b]{2}{*}{$\begin{array}{l}\text { Natural drip } \\
\text { loss, \% }\end{array}$} & \multirow[b]{2}{*}{$\mathrm{pH}_{15}$} & \multirow[b]{2}{*}{$\mathrm{pH}_{24}$} & \multicolumn{3}{|c|}{ Color, CIE Lab } \\
\hline & & & & & $L$ & $a$ & $b$ \\
\hline \multicolumn{8}{|l|}{ Diet } \\
\hline$K$ & $1.67^{\mathrm{A}}$ & $4.17^{\mathrm{A}}$ & $6.36^{\mathrm{ABa}}$ & 6.08 & $61.19^{\mathrm{Aax}}$ & $6.36^{\mathrm{Aa}}$ & 14.39 \\
\hline$K+S$ & $2.25^{\mathrm{ABa}}$ & $4.50^{\mathrm{A}}$ & $6.41^{\mathrm{ab}}$ & 5.98 & $62.82^{\mathrm{ab}}$ & $6.30^{\mathrm{Aa}}$ & 14.01 \\
\hline$K-0.10 \mathrm{MJ} \mathrm{kg}^{-1}$ & $3.12^{\mathrm{BCbx}}$ & $7.22^{\mathrm{B}}$ & $6.33^{\mathrm{Aa}}$ & 5.96 & $63.04^{\text {aby }}$ & $6.23^{\mathrm{Aabx}}$ & 14.51 \\
\hline$K-0.10 \mathrm{MJ} \mathrm{kg}^{-1}+S$ & $3.22^{\mathrm{BCb}}$ & $7.52^{\mathrm{B}}$ & $6.48^{\mathrm{BCb}}$ & 6.02 & $63.31^{\text {aby }}$ & $5.44^{\text {bcy }}$ & 14.38 \\
\hline$K-0.25 \mathrm{MJ} \mathrm{kg}^{-1}$ & $3.97^{\mathrm{Cy}}$ & $7.31^{\mathrm{B}}$ & $6.53^{\mathrm{Cbc}}$ & 6.04 & $65.56^{\mathrm{Bc}}$ & $4.47^{\mathrm{Bd}}$ & 14.20 \\
\hline$K-0.25 \mathrm{MJ} \mathrm{kg}^{-1}+S$ & $3.57^{\mathrm{C}}$ & $7.62^{\mathrm{B}}$ & $6.52^{\mathrm{Cbc}}$ & 6.05 & $63.99^{b c}$ & $5.30^{\mathrm{c}}$ & 14.41 \\
\hline \multicolumn{8}{|l|}{ Analysis of variance } \\
\hline SEM & 0.155 & 0.335 & 0.017 & 0.015 & 0.321 & 0.141 & 0.167 \\
\hline$P$ & $<0.001$ & $<0.001$ & $<0.001$ & 0.190 & 0.002 & $<0.001$ & 0.970 \\
\hline \multicolumn{8}{|l|}{ Energy } \\
\hline$K$ & $1.97^{\mathrm{A}}$ & $4.33^{\mathrm{A}}$ & $6.38^{\mathrm{A}}$ & 6.03 & $62.01^{\mathrm{Ax}}$ & $6.33^{\mathrm{Ax}}$ & 14.20 \\
\hline$K-0.10 \mathrm{MJ} \mathrm{kg}^{-1}$ & $3.17^{\mathrm{B}}$ & $7.37^{\mathrm{B}}$ & $6.41^{\mathrm{AB}}$ & 5.99 & $63.18^{\text {ay }}$ & $5.84^{\text {Ay }}$ & 14.45 \\
\hline$K-0.25 \mathrm{MJ} \mathrm{kg}^{-1}$ & $3.17^{\mathrm{B}}$ & $7.47^{\mathrm{B}}$ & $6.52^{\mathrm{B}}$ & 6.04 & $64.77^{\mathrm{Bb}}$ & $4.88^{\mathrm{B}}$ & 14.31 \\
\hline \multicolumn{8}{|l|}{ Superliv } \\
\hline- & 2.93 & 6.23 & $6.41^{\mathrm{a}}$ & 6.03 & 63.27 & 5.69 & 14.37 \\
\hline+ & 3.01 & 6.55 & $6.47^{\mathrm{b}}$ & 6.02 & 63.37 & 5.68 & 14.27 \\
\hline Analysis of variance & \multicolumn{7}{|c|}{$P$} \\
\hline Energy $(E)$ & $<0.001$ & $<0.001$ & $<0.001$ & 0.320 & 0.001 & $<0.001$ & 0.845 \\
\hline Superliv $(S)$ & $<0.001$ & 0.587 & 0.036 & 0.676 & 0.853 & 0.977 & 0.775 \\
\hline Interaction $(E \times S)$ & 0.724 & 0.999 & 0.073 & 0.082 & 0.079 & 0.020 & 0.791 \\
\hline SEM & 0.300 & 0.335 & 0.017 & 0.015 & 0.321 & 0.141 & 0.167 \\
\hline
\end{tabular}

a, b, c $P \leq 0.05$. A, B, C $P \leq 0.01 .{ }^{\mathrm{x} / \mathrm{y} / \mathrm{z}} 0.05<P \leq 0.10$.

Acidity is measured $15 \mathrm{~min}$ post mortem to distinguish between normal-quality meat and PSE/DFD (pale, soft, exudative/dark, firm, dry) meat. Research shows that the normal pH range of meat is 5.8 (Wójcik et al., 2011) or 5.9 (Żywica et al., 2011) to 6.2 (Wójcik et al., 2011; Żywica et al., 2011). The values below 5.7 and above 6.4 are indicative of PSE and DFD meat, respectively. In the present study, $\mathrm{pH}_{15}$ was 6.36 in the control group, and it ranged from 6.3 to 6.5 in experimental groups. The average $\mathrm{pH}_{24}$ value of chicken meat varies between 5.6 and 6.1 (Berri et al., 2005; Gornowicz and Pietrzak, 2008; Mikulski et al., 2010; Rycielska et al., 2010). The $\mathrm{pH}_{24}$ values determined in our study remain within the upper limit of the normal range. Higher $\mathrm{pH}$ levels are associated with a shorter shelf life of meat since they may promote microbial growth, as well as with a darker color and higher WHC. Such relationships, although nonlinear, were also noted in our study, and they were reflected in the differences between groups 5 and 6 vs. the control treatment. The results of meat color analysis, in particular the values of parameter $L$ (lightness), are difficult to interpret. The re- sults of international studies vary with regard to the $L$ values of PSE, DFD and normal-quality meat. The latter were determined to be 43-56 in Poland (Lesiów et al., 2003), 4166 in Italy (Petracci et al., 2004) and 45-67 in the United Kingdom (Wilkins et al., 2000). According to Branscheid et al. (2004), DFD meat can occur at the normal threshold values (51-57), but normal meat cannot be reliably distinguished from meat with qualitative defects based solely on color lightness. Therefore, advanced methods of meat quality assessment should be applied to identify meat parameters that are the most reliable indicators of quality and to analyze correlations between them. One such technique is cluster analysis (Karpiesiuk et al., 2016).

Water-holding capacity is one of the most important quality attributes of meat, in particular with regard to its processing suitability. In the present study, a decrease in WHC was observed, but it was not associated with the tested herbal preparation. The available literature provides no information on the effect of low-energy diets fed to broiler chickens on meat quality, including WHC and natural drip loss. 
The results of studies investigating the efficacy of herbal additives in broiler chicken nutrition are inconclusive. Reis et al. (2018) reported an increase in the WHC of meat in broiler chickens receiving a feed additive based on essential oils. In a study by Puvača et al. (2014), the addition of garlic powder to broiler diets also led to a significant increase in WHC. On the other hand, no significant differences in the WHC of meat were found between dietary treatments in broiler chickens fed diets supplemented with lavender essential oil (Küçükyilmaz et al., 2016) and lavender powder (Salajegheh et al., 2018).

\section{Conclusions}

Low-energy diets had a negative effect on broiler chicken productivity, whereas the Superliv herbal formula had a beneficial effect on the growth performance.

The herbal feed additive had an influence on heart development; liver weight tended to decrease.

Reduced energy concentration in broiler chickens diets increased fat content in breast muscles; also, lower MDA concentration was noted.

Reduced energy concentration had a negative effect on water-holding capacity and meat acidity. Meat had a lighter color and lower redness content. Superliv had an effect on meat acidity measured 15 min post mortem $\left(\mathrm{pH}_{15}\right)$.

Due to the growth performance results, Superliv may be a valuable fodder additive in broiler chicken nutrition.

Data availability. The data sets are available upon request from the corresponding author.

Author contributions. All of the authors equally contributed to this study.

Competing interests. The authors declare that they have no conflict of interest.

Edited by: Manfred Mielenz

Reviewed by: two anonymous referees

\section{References}

Al-Kassie, G. A. M. and Witwit, N. M.: A comparative study on diet supplementation with a mixture of herbal plants and dandelion as a source of prebiotics on the performance of broilers, Pak. J. Nutr., 9, 61-71, 2010.

Al-Kassie, G. A. M.: The role of peppermint (Mentha pepperita) on performance in broiler diets, Agric. Biol. J. N. Am., 1, 10091013, 2010.

Amad, A. A., Männer, K., Wendler, K. R., Neumann, K., and Zentek, J.: Effects of a phytogenic feed additive on growth perfor- mance and ileal nutrient digestibility in broiler chickens, Poultry Sci., 90, 2811-2816, 2011.

AOAC International: Official methods of analysis of AOAC International, 2005.

Basmacioğlu, H., Tokusoglu, O., and Ergul, M.: The effect of oregano and rosemary essential oils or alpha-tocopheryl acetate on performance and lipid oxidation of meat enriched with $n-3$ PUFA's in broilers, S. Afr. J. Anim. Sci., 34, 197-210, 2004.

Berri, C., Le Bihan-Duval, E., Baeza, E., Chartrin, P., Picgirard, L., Jehl, N., Quentin, M., Picard, M., and Duclos, J.: Further processing characteristics of breast and leg meat from fast-, mediumand slowgrowing commercial chickens, Anim. Res., 54, 123134, 2005.

Bhattacharyya, A., Choudhary, A., Maini, S., and Kotagiri, R.: Effect of supplementation of Superliv Liquid on the performance of Commercial Broilers in Salimpur Poultry Farm of Mathura, Int. J. Advert., 3, 539-543, 2015.

Botsoglou, N. A., Christaki, E., Florou-Paneri, P., Giannenas, I., Papageorgiou, G., and Spais, A. B.: The effect of a mixture of herbal essential oils or $\alpha$-tocopheryl acetate on performance parameters and oxidation of body lipid in broilers, S. Afr. J. Anim. Sci., 34, 52-61, 2004.

Branscheid, W., Hah, G., and Wicke, M.: Quality of turkey meat: Problems and countermeasures, Fleischwirtschaft, 84, 109, 2004.

CIE: Recommendations on uniform color spaces-color difference equations, Psychometric Color Terms, Supplement No. 2 to CIE Publication No. 15 (E-1.3.1) 1978, 1971/(TC-1-3), Commission Internationale de l'E Â Clairage, Paris, 1978.

Demir, E., Kilinc, K., Yildirim, Y., Dincer, F., and Eseceli, H.: Comparative effects of mint, sage, thyme and flavomycin in wheatbased broiler diets, Arch. Zootech., 11, 54-63, 2008.

Giannenas, I. A., Florou-Paneri, P., Botsoglou, N. A., Christaki, E., and Spais, A. B.: Effect of supplementing feed with oregano and(or) alpha-tocopheryl acetate on growth of broiler chickens and oxidative stability of meat, J. Anim. Feed Sci., 14, 521-535, 2005.

Gornowicz, E. and Pietrzak, M.: Wpływ pochodzenia kurcząt brojlerów na cechy rzeźne i jakość mięśni piersiowych, Roczniki Instytutu Przemysłu Mięsnego i Tłuszczowego, 46, 95-104, 2008.

Grau, R. and Hamm, R.: Eine einfache Methode zur Bestimmung der Wasserbindung im Fleisch, Fleischwirtschaft, 4, 295-297, 1952.

Hashemi, S. R. and Davoodi, H.: Phytogenics as New Class of Fees Additives in Poultry Industry, J. Anim. Vet. Adv., 9, 2295-2304, 2010.

Honikel, K. O.: Reference methods for the assessment of physical characteristics of meat, Meat Sci., 49, 447-457, 1998.

Karpiesiuk, K., Falkowski, J., Raubo, B., Kozera, W., and Bugnacka, D.: Wpływ systemu chowu i sposobu żywienia tuczników na ich wartość rzeźną i jakość mięsa, Żywność Nauka Technologia Jakość, 5, 45-59, 2016.

Küçükyilmaz, K., Kiyma, Z., Akdağ, A., Çetinkaya, M., Atalay, H., Ateş, A., and Bozkurt, M.: Effect of lavender (Lavandula Stoechas) essential oil on growth performance, carcass characteristics, meat quality and antioxidant status of broilers, S. Afr. J. Anim. Sci., 47, 178-188, 2017.

Lesiów, T. and Kijowski, J.: Impact of PSE meat on poultry processing - a review, Pol. J. Food Nutr. Sci., 12, 3-8, 2003. 
Lipiński, K., Kaliniewicz, J., Tywończuk, J., and Stasiewicz, M.: Wpływ dodatków probiotycznych i ziołowych na produkcyjność i jakość mięsa indyków, Roczniki Naukowe Zootechniki, 2, 2935, 2011.

Luna, A., Labaque, M. C., Zygadlo, J. A., and Marin, R. H.: Effects of thymol and carvacrol feed supplementation on lipid oxidation in broiler meat, Poultry Sci., 89, 366-370, 2010.

Madhupriya, V., Shamsudeen, P., Manohar, G. R., Senthilkumar, S., Soundarapandiyan, V., and Moorthy, M.: Phyto Feed Additives in Poultry Nutrition: A Review, Int. J. Sci. Educ., 7, 815-822, 2018.

Mikulski, D., Celej, J., Jankowski, J., Majewska, T., and Mikulska, M.: Growth performance, carcass traits and meat quality of flower-growing and fast-growing chickens raised with and without outdoor access. Asian-australas, J. Anim. Sci., 24, 14071416, 2010.

Ogbuewu, I. P., Okoro, V. M., Mbajiorgu, E. F., and Mbajiorgu, C. A.: Beneficial Effects of Garlic in Livestock and Poultry Nutrition: A Review, Agric. Res., 1-16, https://doi.org/10.1007/s40003-018-0390-y, 2018.

Petracci, M., Bianchi, M., Betti, M., and Cavani, C.: Color variation and characterization of broiler breast meat during processing in Italy, Poultry Sci., 83, https://doi.org/10.1093/ps/83.12.2086, 2004.

Pohja, M. S. and Niinivaara, F. P.: Die bestimmung der Wasserbindung des Fleisches mittels der Konstantdruckmethode, Fleischwirtschaft, 9, 193-195, 1957.

Puvača, N., Stanaćev, V., Beuković, M., Ljubojević, D., Kostadinović, L., and Džinić, N.: Effect of phytogenic feed additive (Allium sativum L.) in broiler chicken nutrition on breast meat quality and tissues cholesterol content, in: 7th International Scientific/Professional Conference, Agriculture in Nature and Environment Protection, Vukovar, Croatia, 28-30 May 2014, Croatian Soil Tillage Research Organization, 75-80, 2014.
Reis, J. H., Gebert, R. R., Barreta, M., Baldissera, M. D., dos Santos, I. D., Wagner R., and Mendes, R. E.: Effects of phytogenic feed additive based on thymol, carvacrol and cinnamic aldehyde on body weight, blood parameters and environmental bacteria in broilers chickens, Microb. Pathog., 125, 168-176, 2018.

Rycielska, J., Jarosiewicz, K., and Słowiński, M.: Wpływ wybranych czynników przyżyciowych na jakość mięsa kurcząt, Med. Weter., 66, 770-773, 2010.

Salajegheh, A., Salarmoini, M., Afsharmanesh, M., and Salajegheh, M. H.: Growth performance, intestinal microflora, and meat quality of broiler chickens fed lavender (Lavandula angustifolia) powder, J. Livest. Sci., 6, 31-38, 2018.

Singh, V. K., Chauhan S. S., Ravikanth, K., Maini, S., and Rekhe, D. S.: Effect of dietary supplementation of polyherbal liver stimulant on growth performance and nutrient utilization in broiler chicken, Vet. World, 2, 350-352, 2009.

Sharma, R. K., Maini, S., and Ravikanth, K.: Beneficial effects of Superliv DS and Xlivpro on growth promotion and carcass quality traits in broilers, Vet. World, 1, 363-365, 2008.

Sorensen, G. and Jorgensen, S. S.: A criticial examination of some experimental variables in the 2-thiobarbituric acid (TBARS) test for lipid oxidation in meat products, Z. Lebensm. Unters. Forsch., 202, 205-210, 1996.

Wilkins, L. J., Brown S. N., Philips, A. J., and Wariss, P. D.: Variation in the colour of broiler breast fillets in the UK, Br. Poult. Sci., 41, 308-312, 2000.

Wójcik, A., Pomianowski, J. F., Sowińska, J., Mituniewicz, T., Witkowska, D., Chorąży, Ł., and Piotrowska, J.: Wpływ obrotu przedubojowego kurcząt brojlerów na jakość technologiczną mięsa, Inżynieria i Aparatura Chemiczna, 3, 85-86, 2011.

Żywica, R., Charzyńska, D. G., and Banach, J. K.: Wpływ procesu oszał amiania elektrycznego kurcząt za pomocą urządzenia własnej konstrukcji na barwę mięsa, Żywność Nauka Technologia Jakość, 1, 52-67, 2011. 